\title{
Association between body adiposity index and cardiovascular risk factors in teachers
}

\section{Associação entre índice de adiposidade corporal e fatores de risco cardiovasculares em professores}

\author{
Renata Aparecida Rodrigues de Oliveira ${ }^{1,2}$ \\ (D) https://orcid.org/0000-0002-5004-5253 \\ Osvaldo Costa Moreira \\ (D) https://orcid.org/0000-0002-1386-8883 \\ Rômulo José Mota Júnior ${ }^{1,2}$ \\ (D) https://orcid.org/0000-0001-8434-9493 \\ João Carlos Bouzas Marins ${ }^{1}$ \\ (D) https://orcid.org/0000-0003-0727-3450
}

Abstract - Body adiposity index (BAI) is a relatively recent evaluation method for the diagnosis of overweight and obesity, which takes into account simple measures. The aim of this study was to verify the association between BAI and cardiovascular risk factors in teachers. A cross-sectional study was conducted with 495 teachers from the city of Viçosa-MG. BAI, body mass index (BMI), abdominal circumference (AC), waist-to-hip ratio (WtHR), body fat percentage $(\% \mathrm{BF})$, systolic and diastolic blood pressure, fasting glucose, total cholesterol and triglycerides were evaluated. Associations between BAI (independent variable) and other variables (dependent variable) were evaluated through simple linear regression. Of the total participants, $32.12 \%$ presented high BAI and higher anthropometric, blood pressure and biochemical values $(p<0.05)$. Higher percentage of high BAI was observed among men and with advancing age. Linear regression analysis showed positive association between BAI and other anthropometric measurements $(\mathrm{p}<0.001)$, with glucose $\left(\mathrm{R}^{2}=0.024 ; \mathrm{p}=0.001\right)$ and total cholesterol $\left(\mathrm{R}^{2}=0.028 ; \mathrm{p}<0.001\right)$. BAI was positively associated with the other anthropometric measures (BMI, \%BF, AC and WtHR), and with the glucose and total cholesterol of evaluated teachers. Higher BAI was observed among men and with advancing age.

Key words: Faculty; Obesity; Risk factors.

Resumo - O indice de adiposidade corporal (IAC) é um método relativamente recente de avaliação para o diagnóstico do sobrepeso e obesidade, que leva em consideração medidas simples. Objetivo: Verificar a associação entre $I A C$ e fatores de risco cardiovasculares em professores. Foi realizado um estudo transversal em 495 professores da cidade de Viçosa-MG. Avaliou-se o IAC, indice de massa corporal (IMC), circunferência abdominal (CA), relação cintura-quadril (RCQ), percentual de gordura corporal $(\% G C)$, pressão arterial sistólica e diastólica, glicemia de jejum, colesterol total e triglicerídeos. Avaliaram-se as associaçôes entre o IAC (variável independente) e demais variáveis (variável dependente) através da regressão linear simples. Do total de avaliados, 32,12\% apresentaram o IAC elevado, com estes apresentando maiores valores antropométricos, pressóricos ebioquímicos $(p<0,05)$. Pode-se observar maior porcentagem de IAC elevada entre os homens e com o avançar da idade. A análise de regressão linear mostrou associação positiva entre o IACe as demais medidas antropométricas $(p<0,001)$, com a glicose $\left(R^{2}=0,024 ; p=0,001\right)$ e colesterol total $\left(R^{2}=0,028 ; p<0,001\right)$. O LAC apresentou associação positiva com as demais medidas antropométricas (IMC, \%GC, CA e $R C Q$ ), e com a glicose e colesterol total dos professores avaliados. Pode-se observar maior IAC entre os homens e com o avançar da idade.

Palavras-chave: Docentes; Fatores de risco; Obesidade.
1 Federal University of Viçosa Viçosa, MG. Brazil.

2 "Governador Ozanam Coelho" University Center. Ubá, MG. Brazil.

Received: September 04, 2018 Accepted: January 19, 2019

How to cite this article Oliveira RAR, Moreira OC, Mota Júnior RJ, Marins JCB. Association between body adiposity index and cardiovascular risk factors in teachers. Rev Bras Cineantropom Desempenho Hum 2020, 22:e59010. DOl: http://dx.doi. org/10.1590/1980-0037.2020v22e59010

Copyright: This work is licensed under a Creative Commons Attribution 4.0 International License. 


\section{INTRODUCTION}

Cardiovascular diseases represent the main cause of death in the world, accounting for about $30 \%$ of deaths in Brazil ${ }^{1}$. Obesity is among the risk factors for such diseases, which has increasing prevalence due to the decrease in levels of physical activity and increased caloric intake ${ }^{2}$.

Obesity is associated with increased risk of hypertension, dyslipidemia, type 2 diabetes mellitus, coronary artery disease, osteoarthritis, some types of cancer, among other diseases ${ }^{3}$. Thus, it deserves special attention, as public spending has increased in Brazil due to the increased prevalence of obesity ${ }^{4}$.

Excess adipose tissue is present among obese individuals, and this is a tissue that secretes large number of bioactive mediators and cytokines, such as C-reactive protein and interleukin 6, involved in inflammation, coagulation and fibrionolysis ${ }^{5}$. Thus, there is a need for early assessment of these individuals in order to detect groups at risk and promote behavioral intervention actions (increase levels of physical activity and dietary reeducation) to avoid the continuity of weight gain, and / or even promote body mass reduction.

Thus, studies should seek the best way to diagnose obesity, as there are several anthropometric techniques used in studies conducted in Brazil ${ }^{6-8}$. However, it is noteworthy that there is no perfect technique for the diagnosis of overweight and obesity, in which variations according to genetic and ethnic factors can occur ${ }^{2}$.

Among techniques used, body mass index (BMI) stands out as a simple technique with easy practical application, but it has important limitations, as it is not directly associated with body fat ${ }^{9}$.

Thus, it is important to seek other ways of assessing body adiposity and to establish its relationship with several cardiovascular risk factors. The body adiposity index (BAI) is a relatively recent assessment method that takes into account simple measures, such as height and hip circumference ${ }^{10}$. In addition, this new index showed promising results in studies conducted with Brazilian adults ${ }^{11}$.

Therefore, the aim of the present study was to verify the association between body adiposity index and cardiovascular risk factors in teachers.

\section{METHOD}

A descriptive study with cross-sectional design was conducted with 495 basic education and higher education teachers from the city of Viçosa-MG. Data collection took place at the Human Performance Laboratory of the Department of Physical Education - Federal University of Viçosa (UFV), or at the school where basic education teachers worked, in a reserved room (except for blood parameters).

Sample calculations were performed according to the following equation: $\mathrm{n}=\mathrm{P} \times \mathrm{Q} /(\mathrm{E} / 1.96)^{2}$ 12, obtaining the necessary value to compose 
the sample of basic education and higher education teachers. After this procedure, all teachers from a public university and elementary and high schools (public and private) in the city were invited to participate in the study, but they should meet the following inclusion / exclusion criteria: 1) at least three years of teaching experience; 2) not being on medical or gestational leave; 3 ) not having any organic and / or metabolic impairment that would prevent them from participating in the study.

Initially, the procedures adopted were approved by the UFV Ethics Committee on Human Research (Ref. No. 009/2009 / CEPH, higher education teachers; Ref. No. 070/2012 / CEPH, public high-school teachers and CAAE 48845415.0.0000.5153, private high-school teachers), in accordance with Resolution 466/12 of the National Health Council. Before starting data collection, all participants signed the Free and Informed Consent Form.

Body mass and height were evaluated, allowing BMI calculation; in addition to waist circumference (lower curvature between the last costal arch and the iliac crest), abdomen (at the height of the umbilical scar), hip (region with the largest hip protuberance), with calculation of the waistto-hip ratio (WtHR).

BAI was calculated using hip circumference and height data ${ }^{10}$. For the estimation of excess body adiposity through BAI, the following cutoff point was considered: $25 \%$ for men and $35 \%$ for women ${ }^{13}$.

Body fat percentage (\% BF) was assessed using the skinfold technique, following recommendations of protocols of Jackson and Pollock ${ }^{14}$ and Jackson et al. ${ }^{15}$, with measurement of three skinfolds (Men: Pectoral, Abdomen and Thigh; Women: Triceps, Supra-iliac and Thigh). The Siri's equation ${ }^{16}$ was used to convert body density into \% BF: (\% BF $=[(4.95$ / SF) - 4.50] x 100).

To record systolic (SBP) and diastolic (DBP) blood pressure, the subject remained at rest for 5 minutes in the sitting position. Measurements were performed according to criteria of the Brazilian Society of Cardiology ${ }^{17}$.

For the collection of biochemical parameters among basic education teachers, venous blood samples were used. Such collections were performed between 07:00 am and 09:00 am by a qualified professional at the Clinical Analysis Laboratory of the UFV Health Division after a 12-hour fast. Fasting blood glucose (glucose oxidase method), total cholesterol and triglycerides (enzymatic calorimetric method) were analyzed. The device used for analysis was Cobas Mira Plus (Roche Diagnostics, Montclair, NJ, USA), and kits were obtained from Bioclin-Quibasa company.

Among higher education teachers, biochemical parameters were performed by means of digital puncture, with subject being evaluated on a fasting period of at least four hours. All blood collection and analysis procedures were performed using disposable materials. The equipment used for blood analysis was Accutrend PLUS (Roche, USA), for lipid parameters and Accu-Chek Go (Roche, USA), for glucose. Both devices have been validated in previous studies for triglyceride ${ }^{18}$ and capillary glucose ${ }^{19}$ parameters. 
Data analysis started with the Komolgorov-Smirnov test, with Lilliefors correction, to verify the assumption of normality of variables, with only $\% \mathrm{BF}$ values showing normal distribution. Subsequently, data analysis constituted the descriptive exploration of study variables (mean and standard deviation) and the calculation of relative frequencies. The Student $t$ test was used to compare means between independent groups, and the MannWhitney test was used for non-parametric data. Associations between BAI (independent variable) and other variables (dependent variable) were evaluated using simple linear regression. Logarithmic transformation (base 10) of dependent variables that did not have normal distribution was performed to be used in the linear regression. For all treatments, significance level of 5\% was adopted. All statistical analyses were performed using the SPSS for Windows program, version 20.0 (Chicago, USA).

\section{RESULTS}

Overall, 495 basic and higher education teachers were evaluated, of which 324 were female and 171 were male. Of the total number of individuals evaluated, 32.12\% had high BAI (> 25\% for men and > 35\% for women). Table 1 shows the sample characteristics according to the presence of normal and elevated BAI.

Table 1. Sample characteristics according to body adiposity index, Viçosa-MG.

\begin{tabular}{|c|c|c|c|}
\hline Variables & $\begin{array}{c}\text { Normal BAI } \\
(n=336)\end{array}$ & $\begin{array}{l}\text { High BAl } \\
(n=159)\end{array}$ & P-value \\
\hline Age (years) & $41.78 \pm 10.56$ & $45.23 \pm 10.26$ & $0.001^{*}$ \\
\hline Body mass (kg) & $65.60 \pm 10.78$ & $81.01 \pm 13.87$ & $<0.001^{*}$ \\
\hline Height (m) & $1.66 \pm 0.09$ & $1.64 \pm 0.09$ & $0.176^{\star}$ \\
\hline BMI $\left(\mathrm{Kg} / \mathrm{m}^{2}\right)$ & $23.86 \pm 2.81$ & $30.02 \pm 4.11$ & $<0.001^{*}$ \\
\hline WC (cm) & $78.44 \pm 8.69$ & $92.18 \pm 10.43$ & $<0.001^{*}$ \\
\hline $\mathrm{HC}(\mathrm{cm})$ & $97.48 \pm 6.49$ & $107.40 \pm 9.25$ & $<0.001^{*}$ \\
\hline $\mathrm{AC}(\mathrm{cm})$ & $85.58 \pm 8.77$ & $98.54 \pm 10.76$ & $<0.001^{*}$ \\
\hline WtHR & $0.81 \pm 0.08$ & $0.86 \pm 0.08$ & $<0.001^{*}$ \\
\hline$\% B F$ & $26.76 \pm 7.01$ & $30.72 \pm 8.27$ & $<0.001^{\otimes}$ \\
\hline BAI & $25.96 \pm 4.16$ & $33.45 \pm 6.56$ & $<0.001^{*}$ \\
\hline $\mathrm{SBP}(\mathrm{mmHg})$ & $112.07 \pm 12.51$ & $119.53 \pm 13.48$ & $<0.001^{*}$ \\
\hline $\mathrm{DBP}(\mathrm{mmHg})$ & $73.30 \pm 9.62$ & $76.92 \pm 9.76$ & $<0.001^{\star}$ \\
\hline Glucose (mg/dL) & $86.77 \pm 11.55$ & $92.25 \pm 22.23$ & $0.002^{*}$ \\
\hline $\mathrm{TC}(\mathrm{mg} / \mathrm{dL})^{1}$ & $188.98 \pm 35.06$ & $190.29 \pm 31.65$ & $0.419^{*}$ \\
\hline Triglycerides $(\mathrm{mg} / \mathrm{dL})^{2}$ & $121.60 \pm 64.52$ & $147.09 \pm 70.48$ & $<0.001^{*}$ \\
\hline
\end{tabular}

Note. * Mann-Whitney test; Student Student $t$ test; ${ }^{1}$ Data from 327 teachers with normal BAI and 149 with high BAl; ${ }^{2}$ Data from 326 teachers with normal BAI and 153 with high BAl; BMI: body mass index; WC: waist circumference; HC: hip circumference; AC: abdominal circumference; WtHR: waist-to-hip ratio; \% BF: body fat percentage; BAl: body adiposity index; SBP: systolic blood pressure; DBP: diastolic blood pressure; TC: total cholesterol.

When analyzing BAI according to sex, it was possible to observe that males presented higher percentage in relation to females (Figure 1). While analyzing according to age group, increase with advancing age was observed (Figure 2). 


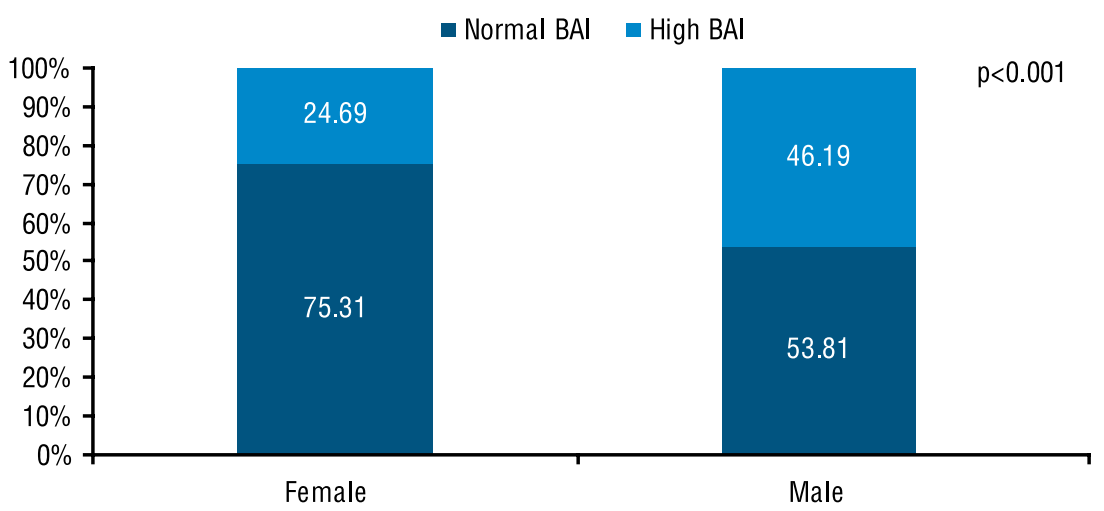

Figure 1. Prevalence of high BAI according to sex, Viçosa-MG. Pearson's chi-square test; BAI: body adiposity index.

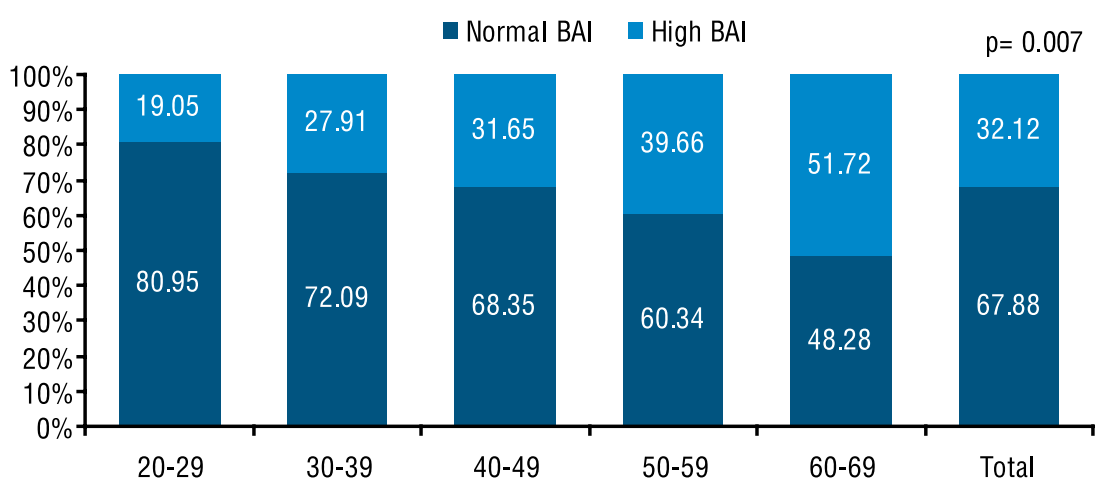

Figure 2. Prevalence of high BAI according to age group, Viçosa-MG. Pearson's chi-square test; BAl: body adiposity index.

Linear regression analysis showed positive association between BAI and the other anthropometric measures (BMI, \%BF, WC and WtHR), although the greatest association was with abdominal circumference, which presented about $58 \%$ of its variation explained by BAI variation. There was also association with glucose and total cholesterol, although the explanatory power of variables was reduced (table 2).

Table 2. Linear regression coefficient between body adiposity index and cardiovascular risk factors of teachers, Viçosa-MG

\begin{tabular}{lcccc}
\hline Dependent variables & $\mathrm{B}$ & $95 \% \mathrm{Cl}$ & $\mathrm{R}^{2}$ & P-value \\
\hline BMI $^{*}$ & 0.008 & $0.007 ; 0.009$ & 0.430 & $<0.001$ \\
\%BF & 1.033 & $0.955 ; 1.110$ & 0.584 & $<0.001$ \\
AC* $^{*}$ & 0.004 & $0.003 ; 0.004$ & 0.143 & $<0.001$ \\
WtHR $^{*}$ & -0.002 & $-0.003 ;-0.001$ & 0.053 & $<0.001$ \\
SBP $^{*}$ & 0.001 & $0.000 ; 0.001$ & 0.006 & 0.076 \\
DBP* $^{*}$ & -2.534 & $-0.001 ; 0.001$ & 0.000 & 0.957 \\
Glucose* $^{*}$ & 0.002 & $0.001 ; 0.003$ & 0.024 & 0.001 \\
Total cholesterol $^{*}$ & 0.002 & $0.001 ; 0.004$ & 0.028 & $<0.001$ \\
Triglycerides & 0.001 & $-0.003 ;-0.004$ & 0.000 & 0.672 \\
\hline
\end{tabular}

Note. \% BF: body fat percentage; AC: abdominal circumference; WtHR: waist-to-hip ratio; SBP: systolic blood pressure; DBP: diastolic blood pressure; * Transformed into logarithm value (base 10). 


\section{DISCUSSION}

The results found in the present study revealed high BAI prevalence among participants (32.12\%), who presented higher values of cardiovascular risk factors (Table 1). The percentage found was similar to that observed in the study by Segheto et al. ${ }^{11}$ in Brazilian adults, with value of 36.89\%; and the study by García et al. ${ }^{20}$, in Colombian adults, with $33.9 \%$.

This result is in agreement with data obtained in Brazil, in which it is possible to observe high values related to obesity. The last telephone survey carried out by the Ministry of Health found overweight prevalence of $53.8 \%$, with $17.7 \%$ of those showing obesity ${ }^{21}$.

These values become relevant, as obesity is associated with several cardiovascular diseases ${ }^{1}$. As observed in the present study, those who had high BAI obtained higher averages for anthropometric, blood pressure and biochemical variables (Table 1). Thus, it is important to emphasize preventive and control measures through dietary reeducation and regular practice of physical activity, aiming to reduce obesity and associated risk factors.

It was possible to verify that males had higher prevalence than females (Figure 1). This result corroborates results obtained by Segheto et al. ${ }^{11}$. In addition, when compared to national data using BMI as anthropometric measure, higher values are also observed among men ${ }^{21}$. Thus, measures such as educational campaigns aimed at this specific group should be carried out in order to reduce this condition. It is known that men are at higher cardiovascular risk compared to women. In addition, men tend to worry less than women about preventive aspects ${ }^{22}$, which may be one of the reasons why women have longer life expectancy ${ }^{23}$.

Increase in BAI with increasing age was also observed (Figure 2). National data also show increase in obesity with advancing age ${ }^{21}$. One of the factors that may favor the increase in body weight with age is the reduction in the level of physical activity and the basal metabolic rate. It is also found that age has been associated with lower levels of physical activity $^{21}$. Therefore, encouraging regular exercise throughout life should be a central focus of public policies.

Thus, prevention campaigns aiming at healthy aging, with adherence to regular practice of physical activity with a view of preventing obesity should be implemented. This is important, since Brazil has been showing an increasing aging process among its population ${ }^{23}$.

BAI was associated with the other anthropometric indicators, and with the glucose and total cholesterol, and the greatest strength of association was with \% BF. A study by Fedewa et al. ${ }^{24}$ found that BAI is a better $\%$ $\mathrm{BF}$ predictor when compared to BMI in young adults, which is a very important point. The authors reported that this index can provide useful estimates of body composition and disease risk in field contexts, where the use of more sophisticated equipment is not feasible.

The use of dual-energy $x$-ray absorptiometry (DEXA) to assess body composition is ideal, but this technology is not available to the population. 
Electrical bioimpedance requires certain preconditions for the record of reliable data, and it is not always possible to follow a correct methodology, which affects the results. Establishing \% BF by anthropometric technique is very practical and quick, but it needs a very well-trained evaluator. Thus, BAI becomes an essential tool.

In Brazil, a validation study in adults also found that although BAI does not replace the other body fat assessment techniques, there was correlation with other methods. Thus, the authors argue that due to its application advantages, it can be an alternative to estimate body fat in the absence of other more complex techniques ${ }^{25}$.

Among biochemical parameters, BAI was associated with glucose and total cholesterol (Table 2). Regarding blood glucose, previous studies found association between BAI and diabetes in hypertensive men and correlation with glucose and insulin in obese men $^{26,27}$. Such association may be due to the increase in the secretion of leptin, resistin and inhibitor-1 of plasminogen activation (PAI-1), which occurs in obesity and can cause insulin resistance ${ }^{28}$.

The association between BAI and total cholesterol observed in the present study has also been reported in a study with adults from Bogotá, in which the authors found that high BAI values are related to worse lipid profiles $^{20}$. In fact, it is known that obesity can contribute to the increase of free fatty acids in the liver and formation of low-density lipoprotein $(\mathrm{LDL}-\mathrm{C})^{29,30}$. Such association deserves attention, as dyslipidemias are involved in the atherosclerotic process.

Finally, the present study had some limitations, such as: 1) the crosssectional design, allowing the occurrence of reverse causality, which can interfere in the interpretation of results; 2) the lack of assessment of the nutritional pattern and the level of physical activity of participants, which could contribute to verify factors associated with BAI.

As practical implication of this study, when the use of more robust measures to assess body composition is infeasible, BAI can be a measure to be used due to its simplicity of application, requiring only an anthropometric tape, since it uses hip circumference and height measurements, becoming an important tool in population epidemiological survey environments.

The need for prevention and control measures among this group of workers is emphasized, as high number of individuals with high BAI were observed. In addition, further studies should be carried out using this measure to assess body adiposity in order to confirm the results found.

\section{CONCLUSION}

BAI showed positive association with the other anthropometric measurements (BMI, \% BF, AC and WtHR), and with glucose and total cholesterol of evaluated teachers. When BAI was analyzed according to sex and age group, higher percentage was observed among men and increase with advancing age. 


\section{COMPLIANCE WITH ETHICAL STANDARDS}

\section{Funding}

We thank Coordenação de Aperfeiçoamento de Pessoal de Nível Superior (Capes) for granting Master's fellowship.

\section{Ethical approval}

Ethical approval was obtained from the local Human Research Ethics Committee - Federal University of Viçosa and protocol (No. 009/2009 / CEPH, higher education teachers; no. 070/2012 / CEPH, public basic education teachers; and no. 48845415.0.0000.5153, private basic education teachers) was written in accordance with standards set by the Declaration of Helsinki.

\section{Conflict of interest statement}

The authors have no conflict of interests to declare.

\section{Author Contributions}

Conceived and designed experiments: RARO, OCM, RJMJ and JCBM. Performed experiments: RARO, OCM, and RJMJ. Analyzed data: RARO, OCM and RJMJ. Contributed with reagents/materials/analysis tools: RARO, OCM, RJMJ, and JCBM. Wrote the paper: RARO, OCM, RJMJ, and JCBM.

\section{REFERENCES}

1. Rocha RM, Martins WA. Manual de prevenção cardiovascular. 1 ed. Rio de Janeiro: Socerj; 2017.

2. Associação Brasileira para o estudo da obesidade e síndrome metabólica. 4 ed. São Paulo: Diretrizes Brasileiras de Obesidade; 2016.

3. American College of Cardiology/American Heart Associaton task force on practice guidelines. Executive summary: Guidelines (2013) for the management of overwheight and obesity in adults: A report of the American Heart Association Task Force on Practice Guidelines and the Obesity Society published by the Obesity Society and American College of Cardiology/American Heart Association Task Force on Practice Guidelines. Based on a systematica review from the The Obesity Expert Panel, 2013. Obesity 2014; 22(2):S5-39.

4. Mazzoccante RP, Moraes JFVN, Campbell CSG. Gastos públicos diretos com a obesidade e doenças associadas no Brasil. Rev Ciên Méd 2012; 21(1-6):25-34.

5. Lau DCW, Dhillon B, Yan H, Szmitko PE, Verma S. Adipokines: molecular links between obesity and atherosclerosis. Am J Physiol Heart Circ Physiol 2005; 288:H2031-41.

6. Pohl HH, Arnold EF, Dummel KL, Cerentini TM, Reuter EM, Reckziegel MB. Indicadores antropométricos e fatores de risco associados cardiovascular em trabalhadores rurais. Rev Bras Med Esporte 2018; 24(1):64-8.

7. Porto DB, Arruda GA, Altimari LR, Cardoso Júnior CG. Self-perceived health among workers at a University Hospital and associations with indicators of adiposity, arterial blood pressure and physical activity habits. Cien Saude Colet 2016;21(4):1113-22. 
8. Oliveira RAR, Mota Júnior RJ, Tavares DDF, Moreira OC, Lima LM, Amorim PRS, et al. Prevalence of obesity and association of body mass index with risk factors in public school teachers. Rev Bras Cineantropom Desempenho Hum 2015; 17(6):742-52.

9. Prentice AM, Jebb AS. Beyond body mass index. Obes Rev 2001; 2(3):141-7.

10. Bergman RN, Stefanovski D, Buchaman TA, Sumner AE, Reynolds JC, Sebring NG, et al. A better index of body adiposity. Obesity 2011; 19(5):1083-9.

11. Segheto W, Hallal PC, Marins JCB, Silva DCG, Coelho FA, Ribeiro AQ et al. Fatores associados e índice de adiposidade corporal (IAC) em adultos: estudo de base populacional. Ciênc Saúde Coletiva 2018; 23(3):773-83.

12. Lwanga WK, Lemeshow S. Sample size determination in health studies: a practical manual. Geneva: World Health Organization; 1991.

13. World Health Organization. Physical status: the use and interpretation of anthropometry. Report of a WHO Expert Committee. Geneva: WHO; 1995

14. Jackson AS, Pollock ML. Generalized equations for predicting body density of men. Br J Nutr 1978;40:497-504.

15. Jackson AS, Pollock ML, Ward A. Generalized equations for predicting body density of women. Med Sci Sports Exerc 1980;12(3):175-81.

16. Siri WE. Body composition from fluid paces and density: analysis of methods. In: Brozek J, Henschel A. Techniques for measuring body composition. Washington: National Academy of Science; 1961.

17. Sociedade Brasileira de Cardiologia. VII Diretrizes Brasileiras de hipertensão. Arq Bras Cardiol 2016;107(3).

18. Barret HL, Dekker Nitert M, D’Emden M, Mclntyre HD, Callaway LK. Validation of a triglyderide meter for use in pregnancy. BMC Res Notes 2014; 7.

19. Meex C, Poncin J, Chapelle JP, Cavalier E. Analytical validation of the new plasma calibrated Accu-Chek test strips (Roche Diagnostics). Clin Chem Lab Med 2006; 44(11):1376-8.

20. García, AI, Niño-Silva LA, González-Ruíz K, Ramírez-Véliz R. Body aciposity index as marker of obesity and cardiovascular risk in adults from Bogotá, Colombia. Endocrinol Nutr 2015; 62(3):130-7.

21. Brasil. Ministério da Saúde. Secretaria de Vigilância em Saúde. Secretaria de Gestão Estratégica e Participativa. Vigitel Brasil 2016: Vigilância de fatores de risco e proteção para doenças crônicas por inquérito telefônico. Brasília: Ministério da Saúde; 2017.

22. Silva SPC, Menandro MCS. As representações sociais da saúde e de seus cuidados para homens e mulheres idosos. Saúde Soc 2014; 23(2):626-40.

23. Instituto Brasileiro de Geografia e Estatística. Brasil: Projeção da população por sexo e idade - Indicadores implícitos na projeção - 2010/2060. 2018. Disponível em: https://www.ibge.gov.br/estatisticas-novoportal/sociais/populacao/9109projecao-da-populacao.html?=\&t= downloads. Acesso em: 26 de julho de 2018.

24. Fedewa MV, Nickerson BS, Esco MR. Associations of body adiposity index, waist circumference, and body mass index in young adults. Clin Nutr 2018; 1-6.

25. Segheto W, Coelho FA, Silva DCG, Hallal PC, Marins JCB, Ribeiro AQ et al. Validity of body adiposity index in prediction body fat in Brazilian adults. Am J Hum Biol 2017; 29(1).

26. Jablonowska-Lietz B, Mrzosek M, Mlodarczyk M, Nowicka G. New indexes of body fat distribution, visceral adiposity index, body adiposity index, waist-to-height ratio, and metabolic disturbance in the obese. Kardiol Pol 2017; 75(11):1185-91.

27. Marcadenti A, Fuchs FD, Moreira LB, Gus M, Fuchs SC. Adiposity phenotypes are associated with type-2 diabetes: LAP index, body adiposity index, and neck circumference. Atherosclerosis 2017; 266:145-50.

28. Campos KE, Sinzato YK, Damasceno DC, Rudge MVC. Obesidade e resistênica à insulina. Femina 2006; 34(9):591-5. 
29. Klop B, Elte JWF, Cabezas MC. Dyslipidemia in obesity: mechanisms and potential targets. Nutrients 2013; 5:1218-40.

30. Franssen R, Monajemi H, Stroes ESG, Kastelein JJP. Obesity and dyslipidemia. Med Clin North Am 2011; 95(5):893-902.

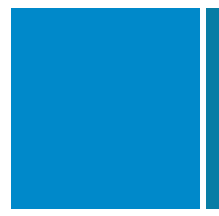

\section{Corresponding author}

Renata Aparecida Rodrigues de Oliveira

Av. Marechal Castelo Branco, 1331 - apto. 202.

CEP: 36576-042 - Viçosa, MG, Brasil

Email: renata.oliveira@ufv.br 